\title{
Enviromental Conservation As an Effort to Form AaWaste Care Community for Rawa Pening Lake
}

\author{
Thriwaty Arsal ${ }^{1}$, Elly Kismini², Antari Ayuning Arsi ${ }^{3}$, Fajar $^{4}$ \\ \{Thriwatyarsal@mail.unnes.ac.id ${ }^{1}$ \} \\ 1,2,3,4Fakultas Ilmu Sosial, Universitas Negeri Semarang, Indonesia
}

\begin{abstract}
The current condition of Rawa Pening Lake is at a high level of damage and pollution. As an effort to minimize the impact of environmental damage, education is needed in the community in the form of education, conservation, care and skills to prevent, detect and anticipate disasters earlier, especially those caused by waste. The aim of the research is to develop environmental conservation to form an environmental care community. This research method uses qualitative research, namely observation, in-depth interviews, Forum Group Discussion (FGD), triangulation of data on key informants and supporters. The research is conducted in Kesongo Village. The analysis used is qualitative analysis of the data from the results of in-depth interviews, observations, and documentation study. The results shows that the pollution and damages that occurred are high sedimentation rates, decreased water quality, damaged water absorption area, the rise of floating net cages, water hyacinth and garbage, flooded downstream, and degradation of lake area thus in this research waste care community of Kesongo Village in Rawa Pening Lake is formed, to provide education and waste management, especially conservation-based household waste.
\end{abstract}

Keywords: Environmental Conservation, Environmental Care Community, Rawa Pening Lake

\section{Introduction}

The study was conducted by Istiawati (2016) [1] regarding conservation education that needs to be instilled through the local wisdom of Ammatoa. Ammatoa is a type of local wisdom that pays attention to aspects of human resources in relation to God, humans, and nature. One aspect that is not explained by Istiawati is how the strategy of implementing Ammatoa's local wisdom values in maintaining the balance and preservation of the natural environment is carried out [1]. A study was conducted by Wardi (2011) [2] about people's perceptions of the environment around them. In addition, waste management driven by cultural awareness still faces many obstacles, such as the lack of awareness from Balinese in good waste management. 
The environment has become an absolute part that cannot be separated from human life. Dirty environment and waste pollution can have a negative impact on both humans and the environment. The problem of waste requires serious attention from various parties because waste is currently still a problem that faces failure in its handling. Humans' ignorance towards waste can exacerbate environmental damage, a definite impact that will certainly occur in society. If waste is not handled properly it will impact on the decline in quality of life, the beauty of the environment and the potential for flooding will be greater because it does not rule out the possibility that waste will block the flow of the water.

One of the impacts caused by waste is a dirty environment and river water pollution. Water pollution can occur when waste is discharged into rivers in areas that cannot be reached by waste cleaning teams such as in remote areas. In addition to polluting river water, the disposal of waste or garbage can also inhibit the process of groundwater. Water is a source of life, in the form of surface water, water in the soil, sea water, or lake water. Lake is a form of freshwater ecosystem that exists on the surface of the earth. In general, lakes are mainland waters which have important functions for human development and life. Lake has three main functions, which are the functions of ecology, cultivation and socio-economic. As seen from the ecological aspect, lake is the place where the ecological cycle of the components of water and aquatic life takes place. The existence of a lake will affect the balance of the surrounding ecosystem, whereas the condition of a lake is also influenced by the surrounding ecosystem. Whereas when seen through the aspect of cultivation, people around the lake often conducting floating fish farming and from socioeconomic aspects, lakes have functions that are directly related to the lives of people around the lake [3].

The results of the research from Jati (2013) show various efforts made by Boyolali government in managing urban environmental waste. In addition, Boyolali government as regulator and waste service provider not only provide waste landfill, but also provide assistance in waste management with a touch of knowledge given to the community [4]. While the results of the research from Yogiesti (2010) [5] show that the lack of direct involvement from the community has a less positive impact on waste management. Therefore, the direction of community empowerment in waste management needs to focus on the concept of participatory development.

Various problems that have been previously explained including their impact as a result of a non-environmentally friendly behavior have raised concerns to build awareness and environmentally friendly community behavior. The combination of environmental conservation based on the culture (local wisdom) of the community will provide many benefits, some of which are bringing people closer to their culture and other benefits, for example in health aspect. Local wisdom is an identity that determines the identity, dignity and human dignity of the community [6]. Armed with the root of the problem culturally and socially, environmental conservation through the revitalization of wisdom expressed through environmental conservation behavior can be realized. In this domain, the flow and research work will be applied through $3 \mathrm{R}$ (Reuse, Deduce, and Recycle) innovation. 


\section{Research Method}

The research was conducted in Kesongo Village, Tuntang District, Semarang Regency, Central Java. This village is one of the villages in the Rawa Pening Lake tourism area. The reason for choosing this location as a research location is; first, this village is an area filled with waste that accumulates in Rawa Pening which resulting in water pollution which decreases fishermen's income because fewer fish are caught. Second, so far the condition of the lake has experienced a decline in the quality of the ecosystem due to excessive use of the lake which has caused degradation of the lake area. Third, in the last few years, there has been a significant socio-cultural change in Kesongo Village along with the increasing capital investment from external party which has made Rawa Pening Lake tourism object increased. In addition to influencing the social and cultural systems of the community, the rise of tourism business investment has also resulted in ecological degradation of the lake due to the accumulation of waste in several villages around the lake. Qualitative data analysis, collection techniques, and validity were carried out by observation, interviews, documentation and data triangulation.

\section{Research Results and Discussions}

Kesongo Village, Tuntang District, Semarang Regency has a development plan to increase the economic income of Kesongo residents by utilizing the abundant natural resources of water hyacinth that thrives on the Rawa Pening lake. Currently, the residents have started the plan by saving money to buy tools used to process water hyacinth. According to one of the community leaders in Kesongo Village, unprocessed water hyacinth will cause rubbish at Rawa Pening Lake, therefore the community will work together to clean the lake while processing the water hyacinth.

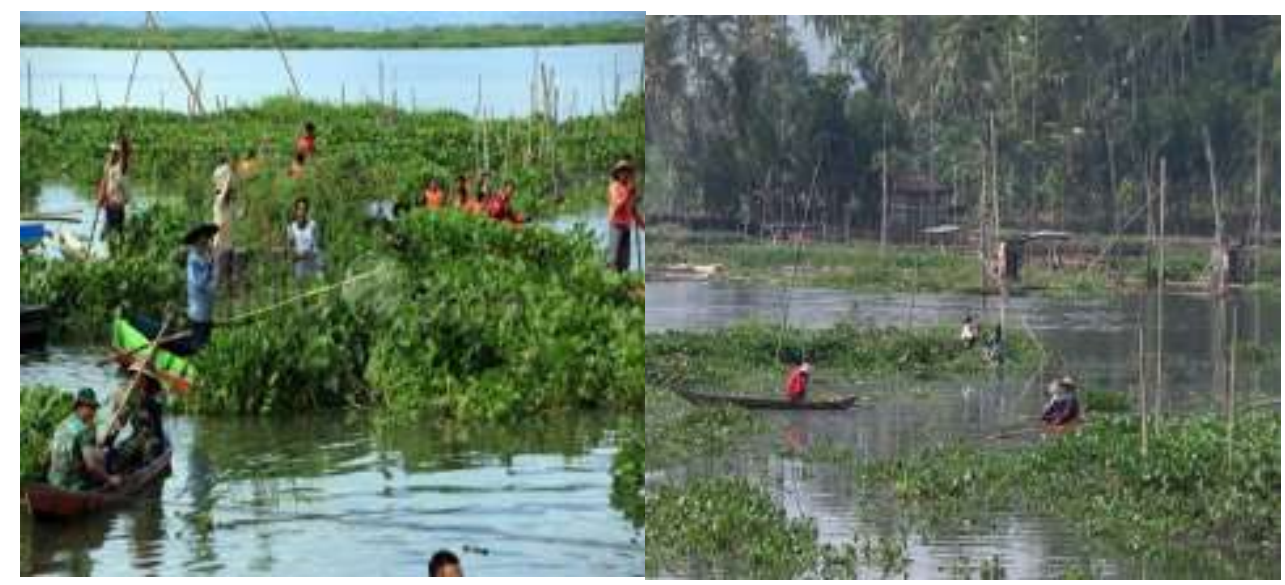

Gambar 1. Tanamn Eceng Gondok yang menutupi permukaan Danau Rawa Pening 
https://kampungternakbinasakinah.wordpress.com/2016/07/19/rawa-pening-darurat-encenggondok/

Figure 1 shows the water hyacinth plants that cover the surface of Rawapening Lake. Residents already have plans to process water hyacinth into handicrafts or handicrafts produced from their own work, starting from clearing water hyacinth from Rawa Pening Lake to the marketing process. Actually, some residents have started trying to produce water hyacinth crafts, but it failed and did not bring profits due to the lack of marketing. However, since 2 years ago the government, especially the village government of Kesongo itself, has begun preparing funds to process water hyacinth. The village government has also collaborated with several big craftsmen group to help market the products

Water hyacinth flourishes in swamps which resulting in them partially covering the swamp, therefore using water hyacinth as a handicraft is indeed the correct move, it can actually provide income for Kesongo residents. Currently, residents only cleave water hyacinth which is then dried and sold, however if the water hyacinth is processed properly it will bring financial income.

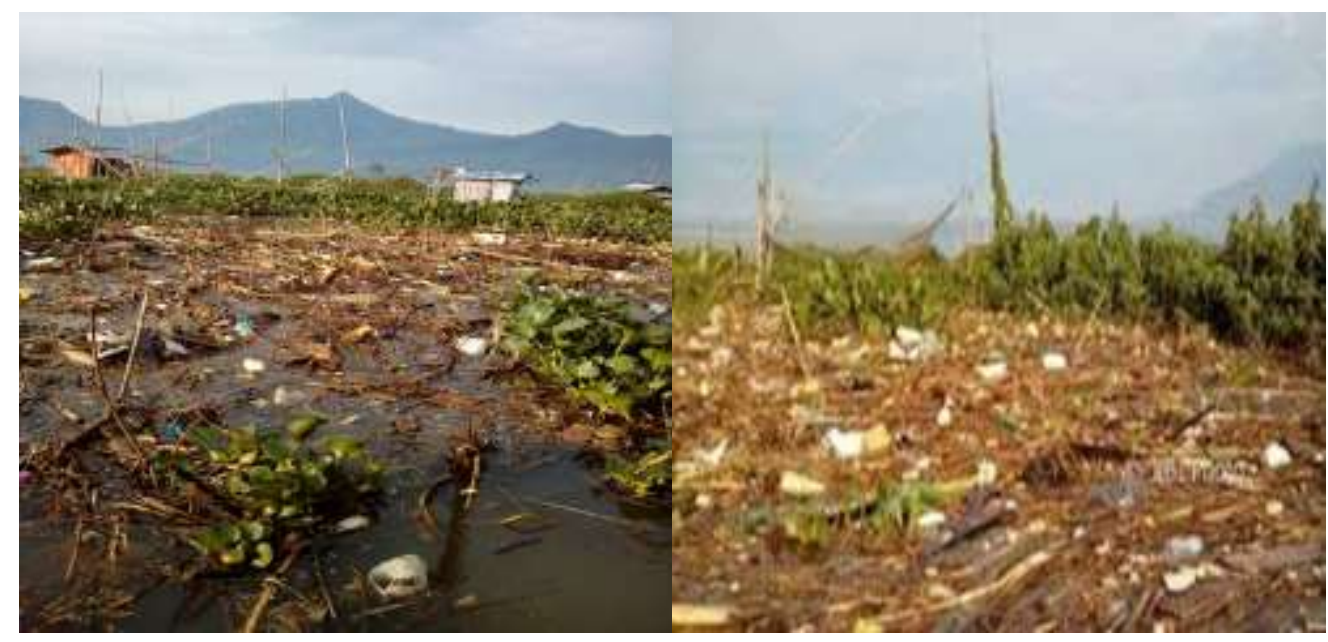

Gambar 2. Danau Rawa Pening yang penuh sampah https://www.salatigacity.com/wp-content/uploads/2017/03/save-rawa-pening-4.jpg

Figure 2 shows a pile of rubbish in Lake Rawa Pening that is damaging to the environment. The problem faced by Kesongo Village is not only about water hyacinth, but also the problem of waste that covers a part of Rawa Pening Lake's surface. According to one informant, the community has not fully realized the importance of protecting the environment by not throwing waste into the lake. So far, the community has been appealed through socialization not to dispose waste, especially household waste, by making waste landfills or recycling them. 
Rawa Pening Lake is one of 15 (fifteen) lakes that are included in the priority list of lake damage recovery in Indonesia based on the 2009 Bali Agreement on Sustainable Lake Management. The current condition of Rawa Pening Lake is at a high level of damage and pollution. Some of the pollutions and damages that occur are high sedimentation rates, decreased water quality, damage to water absorption areas, the rise of floating net cages, water hyacinth and waste, floods in the downstream area, and so forth. Rawa Pening Lake has functions as Hydroelectric Power Plant, agricultural irrigation, fisheries, tourism, sources of livelihood, and flood control. But so far, the condition of the lake has experienced a decline in the quality of the ecosystem due to excessive use of the lake which has caused degradation of the lake area.

Rawa Pening Lake acts as a source of life for the community because it is inseparable from a variety of community activities that are increasing according to (Retnaningsih, 2011; Kentasa, 201; Connell \& Millner, 1995) [7] along with the course of development in the region. However, the lack of public awareness in maintaining and managing Rawa Pening natural resources, especially communities that still dispose organic waste, resulting in nutrient enrichment or eutrophication, thus it is necessary to conserve lakes. Lake Rawa Pening has functions as Hydroelectric Power Plant, agricultural irrigation, fisheries, tourism, sources of livelihood, and flood control, a mainstay tourist attraction in Central Java, and water sources for surrounding communities.

The environment becomes an absolute part that can not be separated in human life. Dirty environment and garbage pollution can have a negative impact, both on humans and on the environment. The problem of waste requires serious attention from various parties because garbage is still a problem that has failed in handling. Human ignorance of waste can exacerbate environmental damage, the impact that will certainly occur in the community if the handling of waste is not handled properly will have an impact on declining quality of life, environmental beauty and the potential for flooding will be greater because it does not close the possibility of garbage will obstruct the flow of water.

\section{Conclusions}

The current condition of Rawa Pening Lake is at a high level of damage and pollution. As an effort to minimize the impact of environmental damage education is needed, especially conservation education in the community in the form of knowledge, understanding, preparedness, caring, and skills to prevent, detect and anticipate early disasters, especially those caused by waste, and not to throw waste arbitrarily especially in Rawa Pening Lake to maintain the continuity and sustainability of the lake.

\section{References}

[1] N. F. Istiawati, "Pendidikan karakter Berbasis Nilai-nilai Kearifan lokal Adat AMMATOA dalam menumbuhkan karakter konservasi," CENDEKIA J. Pendidik. dan Pembelajaran, vol. 10, no. 1, pp. 1-18, 2016.

[2] I. N. Wardi, "Pengelolaan sampah berbasis sosial budaya: Upaya mengatasi masalah 
lingkungan di Bali,” Bumi Lestari J. Environ., vol. 11, no. 1, pp. 167-177, 2011.

[3] I. Fitri, "Pengaruh Resiko Kredit Yang Diberikan dan Tingkat Likuiditas Terhadap Profitabilitas Perbankan Yang Terdaftar di Bursa Efek Indonesia."

[4] T. K. Jati, "Peran Pemerintah Boyolali Dalam Pengelolaan Sampah Lingkungan Permukiman Perkotaan (Studi Kasus: Perumahan Bumi Singkil Permai)," J. Wil. dan Lingkung., vol. 1, no. 1, pp. 1-16, 2013.

[5] V. Yogiesti, S. Hariyani, and F. R. Sutikno, "Pengelolaan sampah terpadu berbasis masyarakat Kota Kediri," J. Tata Kota dan Drh., vol. 2, no. 2, pp. 95-102, 2012.

[6] C. Geertz, "Pengetahuan Lokal.(diterjemahkan oleh: Vivi Mubaikah dan Apri Danarto)," Yogyakarta: Rumah Merapi, 2003.

[7] R. J. Milner, P. Samson, and R. Morton, "Persistence of conidia of Metarhizium anisopliae in sugarcane fields: Effect of isolate and formulation on persistence over 3.5 years," Biocontrol Sci. Technol., vol. 13, no. 5, pp. 507-516, 2003.

Cordell, C.E., Anderson, R.L., Hoffard, W.H., Landis, T.D., and Smith, R.S. Jr. 1989. Soil-Pest Relationship. Department of Agriculture, Forest Service. Agriculture Handbook, 680: 184 (internet).

Darmawan, Darwis \& Fadjarajani, Siti. 2016. Hubungan Antara Pengetahuan dan Sikap Pelestarian Lingkungan dengan Perilaku Wisatawan dalam Menjaga Kebersihan Lingkungan (Studi di Kawasan Objek Wisata Alam Gunung Galungan Desa Linggarjati Kecamatan Sukaratu Kabupaten Tasikmalaya). Jurnal Geografi, Vol. 4, No. 1, April.

Fathony, dkk. 2014. Model Konservasi Sungai Mewek (Studi Kasus: Sungai Mewek Kelurahan Tasikmadu-Tunjungsekar Kota Malang). Prosiding Temu Ilmiah IPLBI 2014. Hal. $1-6$.

Patton, M. Q. 1990. Qualitative Evaluation and Research Methods. London: Sage Publication.

Prasetyo, Budi. 2012. Studi Pemodelan Desa/Kelurahan Konservasi di Kawasan Hulu Das/Ws Brantas. Jurnal Politik Indonesia, Vol.1, No.2, Oktober-Desember. Hal. 6-13. 